\title{
WORKING TIME INTERVALS AND TOTAL WORK TIME ON NURSING POSITIONS IN POLAND
}

\author{
WYMIAR CZASU PRZERW W PRACY A CAŁKOWITY CZAS PRACY \\ NA STANOWISKACH PIELĘGNIARSKICH W POLSCE
}

Pomeranian Medical University / Pomorski Uniwersytet Medyczny, Szczecin, Poland

Faculty of Health Sciences, Department of Public Health / Wydział Nauk o Zdrowiu, Katedra i Zakład Zdrowia Publicznego

\begin{abstract}
Background: For the last few years a topic of overwork on nursing posts has given rise to strong discussions. The author has set herself a goal of answering the question if it is a result of real overwork of this particular profession or rather commonly assumed frustration of this professional group. The aim of this paper is to conduct the analysis of working time on chosen nursing positions in relation to measures of time being used as intervals in the course of conducting standard professional activities during one working day. Material and Methods: Research material consisted of documentation of work time on chosen nursing workplaces, compiled between 2007-2012 within the framework of a nursing course at the Pomeranian Medical University in Szczecin. As a method of measurement a photograph of a working day has been used. Measurements were performed in institutions located in 6 voivodeships in Poland. Results: Results suggest that only 6.5\% of total of surveyed representatives of nurse profession spends proper amount of time (meaning: a time set by the applicable standards) on work intervals during a working day. Conclusions: The scale of the phenomenon indicates excessive workload for nursing positions, which along with a longer period of time, longer working hours may cause decrease in efficiency of work and cause a drop in quality of provided services. Med Pr 2015;66(2):165-172
\end{abstract}

Key words: nurse, fatigue, rest, work, workplace violence, professional misconduct

\begin{abstract}
STRESZCZENIE
Wstęp: W ostatnich latach nasilają się dyskusje na temat zbyt dużego obciążenia pracą na stanowiskach pielęgniarskich. Żeby odpowiedzieć na pytanie, czy wynika to $\mathrm{z}$ rzeczywistego przeciążenia pracą $\mathrm{w}$ tej grupie zawodowej, czy powszechnie przypisywanej jej frustracji, za cel poniższego opracowania przyjęto analizę czasu pracy na stanowiskach pielęgniarskich w odniesieniu do wymiaru czasu poświęcanego na przerwy w codziennych czynnościach zawodowych. Materiał i metody: Materiał badawczy stanowiła dokumentacja pomiarów czasu pracy na wybranych pielęgniarskich stanowiskach pracy. Pomiary wykonano w latach 2007-2012 w ramach zajęć dydaktycznych na kierunku pielęgniarskim na Pomorskim Uniwersytecie Medycznym w Szczecinie. Zostały przeprowadzone w placówkach znajdujących się na terenie 6 polskich województw. Jako metodę pomiarów przyjęto fotografię dnia pracy. Wyniki: Uzyskane wyniki wskazują, że jedynie 6,5\% badanych pielęgniarek przeznacza na przerwy odpowiedni czas w ciągu dnia roboczego, tzn. zgodny z przyjętymi normami. Wnioski: Skala problemu świadczy o nadmiernym obciążeniu pracą na stanowiskach pielęgniarskich. W przyszłości może to skutkować spadkiem efektywności wykonywanej pracy i jakości świadczonych usług. Med. Pr. 2015;66(2):165-172

Słowa kluczowe: pielęgniarka, zmęczenie, odpoczynek, praca, przemoc w miejscu pracy, przewinienie zawodowe

Corresponding author / Autorka do korespondencji: Danuta Kunecka, Department of Public Health, Faculty of Health Sciences, Pomeranian Medical University, Żołnierska 48, 71-210 Szczecin, Poland, e-mail: danuta.kunecka@pum.edu.pl

Received: July 17, 2014, accepted: December 2, 2014
\end{abstract}

\section{INTRODUCTION}

During the last few years, the health care sector in Poland has undergone continuous processes of reorganization aiming mostly at optimization of financial capital. Fairly often were those changes introduced in an atmosphere of "lack" of social support, and sometimes even direct disagreement of medical staff, who publically discussed a risk of significant increase in work overload in the majority cases of all hitherto existing professionals of this sector. It could be that this most represented group of medical professionals in Poland, which nursing environment truly is, is seen through the prism of this look of public opponents as stereotypically frustrated or "difficult." Willingness to be objective in this discussion has caused the author of this elaboration to have decided to examine the Polish reality in relation to problems of overwork on nursing work positions. 
Terminology of time of work is often linked with the term of overwork [1-8] as well as methods of measurement $[9,10]$ or such elements of work which might be consequences of overwork. Fatigue [4,9,11], ways of preventing sleeping or levelling its results at workplace [12] by means of rational rest, for example, during work time intervals $[7,11]$, appeared to the author to be the most popular phrases.

The analysis of literature, however, has directed the research process towards terms strictly connected with the subject of work time intervals, which have often been pointed as the simplest yet most successful approach to counteract overwork at workplace. Abidance by a few basic rules, favors existence of intervals in both quantitative and qualitative context. This might become a great countermeasure for a feeling of being overworked or exhausted [11] and effectively protect employees and a whole organization against further development of negative effects of lack of intervals. Therefore the research problem has been formulated on the basis of the question: what is an assessment of time of intervals on nursing positions in Poland? Few-year observation being an answer to that question prompts the author to a critically formulated hypothesis: nursing positions in Poland are in significant proportion subject to non-compliance with proper proportions of working time intervals in relation to a whole working time, which might result in overwork of an employee, causing further loss of efficiency or quality of provided services. Consequences of this state directly affect an employee.

\section{The aim}

The aim of this paper is to conduct the analysis of working time on chosen nursing posts in relation to measures of time being used as intervals to conducting normal professional activities during one working day.

\section{MATERIAL AND METHODS}

Research material has been composed of documentation of working time measures within the framework of classes: management in nursing during a nursing course taking place annually at one of the Medical Universities. Measurements were performed in institutions located in 6 voivodeship in Poland. As a necessity for this elaboration, photographs of daily work have been chosen. The photographs having been taken in the years: 2007-2008 and 2008-2009 have been chosen as the research group A with 177 people/positions as well as 2010-2011 and 20112012 creating the research group B with 207 people/ positions. The joint analysis of 384 sheets documenting working time measures on nursing positions chosen by students. Socio-demographic data characterizing "photographed" people/positions, that is: length of seniority, education level as well as specificity of working place along with data identifying working place itself, in further parts of the paper have been set as independent variables and portrayed in the Table 1.

Percentage distribution gained from the surveyed group reflects proportions close to majority of nursing environment in Poland. A variable of education level is the exceptiton to this. Most likely, a significant percentage of bachelor level in both groups has been caused by the fact that measures have been taken by students of secondary degree at the Pomeranian Medical University in Szczecin. This group constituted majority of those surveyed. For the purposes of the statistical analysis the following characteristics variables were classified:

treatment is not the specificity - including internal units and specialists in the field of cardiology, rheumatology, gastroenterology, neurology, diabetology, nephrology and primary health care;

treatment specificity - including surgical wards and specialists in the field of neurosurgery, cardiac surgery, urology, dialysis;

non-specific jobs - including social welfare home, spa, crèche, ambulance, operating theater;

non-specific jobs (12 h system) - including a medical dispatcher, operating nurse, medical educator.

The above adopted criteria have been defined based on evaluation of job positions (degree of job difficulty), and not just specificity of workplace.

As a method of working time measurement, a photography of working day has been chosen [9], as one of the methods of constant observation [13]. It allows to get a full view and structure of all activities and intervals during the whole observation. The surveyed group expressed mostly 2 of its kinds: an individual photography of daily work, 232 people, which constituted $60.4 \%$ of total measures, as well as a self-photography of 152 people, which constituted $39.6 \%$ of total measures. Measures that have not pointed as to what kind of measure they might refer to, have been disqualified. The process has been documented on previously prepared sheets of working time measures, on individually pointed working position of a nurse. This sheet has been composed of 3 parts:

the descriptive part - containing characteristics of a given employee, a surveyed work position, as well as organizational conditions of a "photographed work day;" 
Table 1. Characteristics of study group

Tabela 1. Charakterystyka badanej grupy

\begin{tabular}{|c|c|c|c|c|}
\hline \multirow{3}{*}{$\begin{array}{l}\text { Variable } \\
\text { Zmienna }\end{array}$} & \multicolumn{4}{|c|}{$\begin{array}{l}\text { Group* } \\
\text { Grupa }^{*}\end{array}$} \\
\hline & \multicolumn{2}{|c|}{$\begin{array}{c}\mathrm{A} \\
(\mathrm{N}=177)\end{array}$} & \multicolumn{2}{|c|}{$\begin{array}{c}\mathrm{B} \\
(\mathrm{N}=207)\end{array}$} \\
\hline & $\mathrm{n}$ & $\%$ & $\mathrm{n}$ & $\%$ \\
\hline \multicolumn{5}{|l|}{ Workplace / Miejsce pracy } \\
\hline non-treatment specifity / specyfika niezabiegowa & 77 & 43.5 & 72 & 34.8 \\
\hline treatment specifity / specyfika zabiegowa & 42 & 23.7 & 31 & 14.9 \\
\hline intensive care unit / intensywny nadzór medyczny & 22 & 12.4 & 36 & 17.4 \\
\hline non-specific nursing workplaces / niespecyficzne miejsca pracy pielęgniarskiej & 35 & 19.8 & 67 & 32.4 \\
\hline lack of answer / brak odpowiedzi & 1 & 0.6 & 1 & 0.5 \\
\hline \multicolumn{5}{|l|}{ Position / Stanowisko } \\
\hline general nurse / pielęgniarki odcinkowe & 114 & 64.4 & 114 & 55.1 \\
\hline $\begin{array}{l}\text { nurse managers and other independent positions / pielęgniarska kadra zarządzająca } \\
\text { i inne samodzielne pielęgniarki }\end{array}$ & 38 & 21.5 & 40 & 19.3 \\
\hline $\begin{array}{l}\text { functional nurses (working system } 1 \text { shift) / pielęgniarki funkcyjne (system pracy } \\
\text { 1-zmianowy) }\end{array}$ & 13 & 7.3 & 29 & 14.0 \\
\hline $\begin{array}{l}\text { non-specific working positions (12-h system) / niespecyficzne stanowiska pracy } \\
\text { (system 12-godzinny) }\end{array}$ & 9 & 5.1 & 17 & 8.2 \\
\hline lack of answer / brak odpowiedzi & 3 & 1.7 & 7 & 3.4 \\
\hline \multicolumn{5}{|l|}{ Seniority [years] / Staż pracy [w latach] } \\
\hline$\leq 5$ & 67 & 37.8 & 34 & 16.4 \\
\hline $6-15$ & 40 & 22.6 & 47 & 22.7 \\
\hline$\geq 16$ & 70 & 39.5 & 115 & 55.5 \\
\hline lack of answer / brak odpowiedzi & 0 & 0.0 & 11 & 5.3 \\
\hline \multicolumn{5}{|l|}{ Education level / Wykształcenie } \\
\hline secondary education (vocational) / średnie (liceum, studium medyczne) & 15 & 8.5 & 50 & 24.1 \\
\hline bachelor of nursing / licencjat pielęgniarstwa & 157 & 88.7 & 125 & 60.4 \\
\hline $\begin{array}{l}\text { master degree in nursing or other university degree / magister lub inne wyższe } \\
\text { studia magisterskie }\end{array}$ & 5 & 2.8 & 5 & 2.4 \\
\hline lack of answer / brak odpowiedzi & 0 & 0.0 & 27 & 13.0 \\
\hline
\end{tabular}

* Photographs of day in years / Fotografie dnia w latach: 2007-2009 (group / grupa A), 2010-2012 (group / grupa B).

the core part - including chronologically sorted activities and their time, presented in tables;

the summarizing part - including final results received on a given position, constituting the complex view of the source material for this paper.

Due to a low percentage of positions, in which strict standards have been held in regard a certain group of times (direct care, indirect care and intervals) - for the purpose of the analysis - the author has assumed the so called "wide norms." It has been assumed that those values are correct to have been classified as unsubstantial for particular groups deviation (for direct care by $\pm 10 \%$ of the assumed value, for indirect care by $\pm 15 \%$ of the assumed value, for intervals by $\pm 2 \%$ of the assumed value). The specificity a given work position and organizational circumstances accompanying the measuring process have been concurrently taken into consideration.

The statistical analysis of gathered material has been conducted based on Microsoft Excel and statistical software Statsoft, Inc. (2010) Statistica 9.1. During the preliminary analysis the gathered material has been described by numbers and their respective percentages (percentage distribution of answers has been expressed in absolute terms - "N" sample size and percentage 
values). In a further analysis, while looking for dependencies between the assumed survey variables, a test of $\mathrm{Chi}^{2}$ has been used. In justified cases the $\mathrm{Chi}^{2}$ test with the correction of Yates or Fisher's test was used, where the level of significance was assumed at $\mathrm{p}=0.05$.

\section{RESULTS}

Results confirmed the previously stated hypothesis, indicating a significant deviation from the assumed - by the International Labour Organization - minimal values of working time intervals during total working time. Only $6.5 \%$ of the total number of "photographed" work positions have met the criteria of $12 \%$ value for women and $10 \%$ for men $[7,11]$. Moreover for the purpose of this elaboration, the author has comparatively analyzed changes going on in the observed group of nursing positions during the last 5 years. Therefore the surveyed material has been divided into groups, and the analysis has been based on the documentation of working time measures, conducted during 2007-2009 - the group A and 2010-2012 - the group B. Results from those groups are presented in the Figure 1.

The Figure 1 clearly shows that, interpreting only the right values, it is seen, that there is a positive trend in pursuance of the right proportion of working time intervals and total working time on nursing positions. Nonetheless the complex analysis cools down this optimism, due to the fact that this happens with a cost of deepening organizational irregularities.

In the further analysis aiming at surveying mutual correlations between chosen variables, a Chi ${ }^{2}$ test has been used. Results provided by this analysis are presented in the Table 2.

As it is stated in the Table 2, correlating a variable of working time with variables of: work position, place, seniority and level of education, none of the people conducting nursing actions on a "photographed" position, during the day of surveying, has confirmed that the hypothesis zero is wrong, given the assumed lack of mutual correlation between the surveyed phenomena.

The result allowing rejection of the hypothesis zero has been received in the correlation of working time intervals in the case of direct and indirect care. This, however, due to the necessity of using a test with Yates, in the first case does not confirm a positive result, therefore it has been assumed that the mutual cooperation between surveyed phenomena appears only between working time intervals measures and the measure of direct care. To survey the mutual strength of this relation, the Fisher's exact test has been used and its results are presented in the Table 3.

The results of the analysis have confirmed existence of mutual correlation between the surveyed phenomena in the surveyed group. They are, however, inclining to pretty cautious thinking.

Moreover, conducting this before the mentioned analysis, the author had noticed certain trends appearing in the surveyed group. It allows to point 67 "role model" working places (out of 384 people who were surveyed). This group included those positions that had results between the set for the purposes of the surveyed standards, in particular the group of times: direct care, indirect care and intervals. Their characteristic are shown in the Table 4.

While reading the results shown in the Table 4 , a "role model" of a nursing position can be created, pointing out to the fact, that during measuring of working time, they have been observed as those with significantly more cases of compliance with standards. It could be said that those are: positions of management (ward and coordinating nurses belong to that group) on wards with treatment specificities (represented majorly by surgical wards), activities conducted by people, who either have not wished to provide the length of seniority or with seniority of over 16 years (highest provided) as well as with a master's degree (nursing or any others).

\section{DISCUSSION}

It has been becoming more apparent during the recent years in the health sector that there are imperfections connected with unknowingness of rules of proper management, including working time management. A proper structure of working time is often trivialized in relation to effectiveness and efficiency of a given organization. Flexibility is a commonly pointed tool, allowing for adjustments to the needs of the market [7]. The issue is that it is from an employer's point of view, which makes it highly risky, especially when related to the health care sector, in which in such a direct way a state of another person (patient) is dependant. Therefore, very important elements for supporting a stable level of nurse's efficiency an employee, are proper measures of intervals during working time.

Results constitute a clear indicator of irregularities in the structure of working time on nursing positions, therefore its non optimal and unsatisfying model, for none of the parties participating in the process of providing medical services, meaning: employees, employers as well 


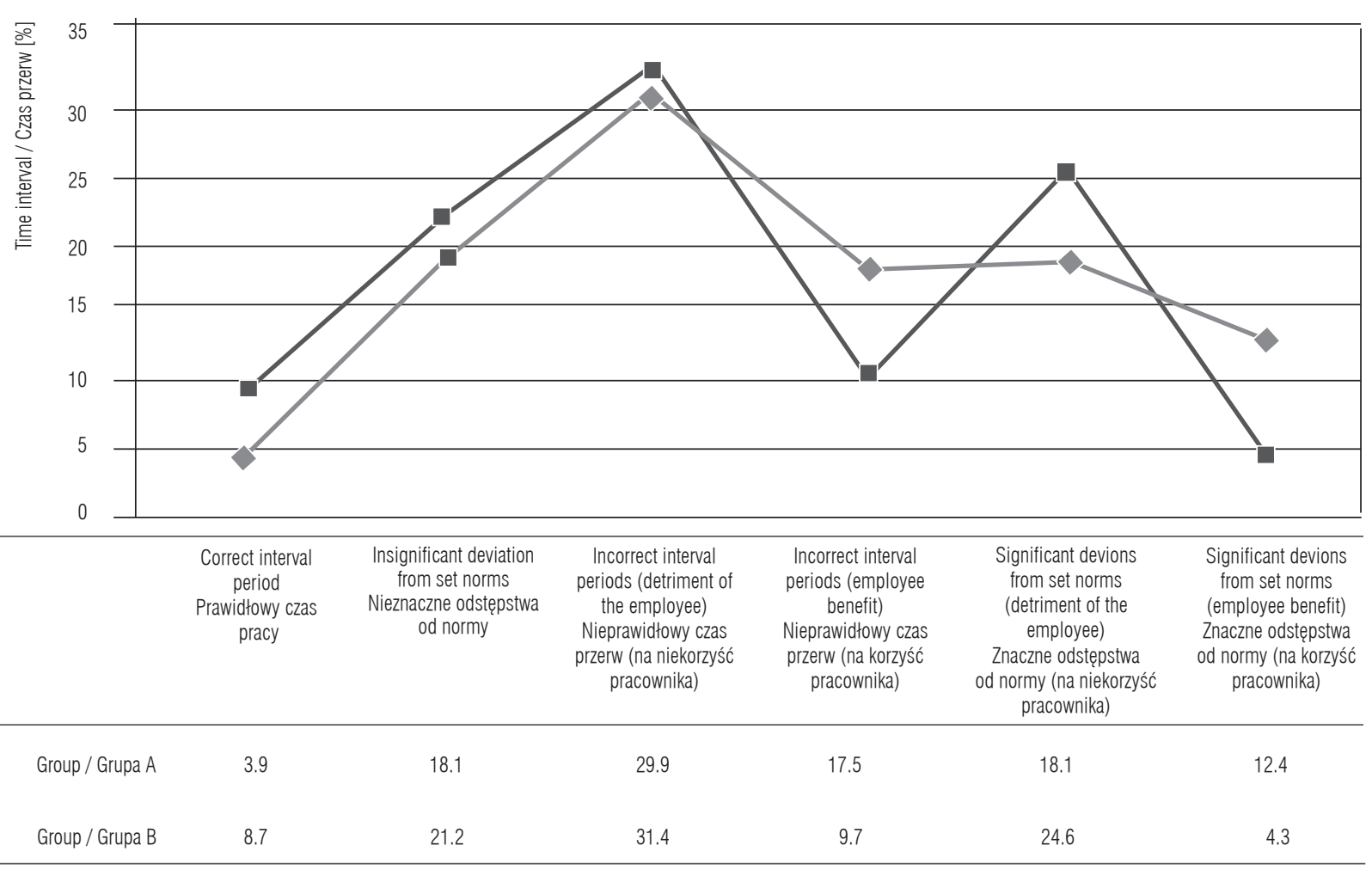

Groups as in Table 1.

Fig. 1. Time interval measure vs. total working time in the surveyed group Ryc. 1. Wymiar czasu przerw vs całkowity czas pracy w badanej grupie

as patients. Other authors came to a similar conclusion, both in Poland and the whole world [13-19].

Due to the aim of this elaboration, a specific analysis has been conducted on measures of intervals compared to overall working day. In this thematically similar research, the analysis concerned mostly working time of: direct and indirect care, as well as mutual relations between them. Therefore fairly often, in the course of results elaboration, were the values received in matters of working time intervals omitted. They have been seen as a component of indirect care, or non-nursing activities $[13,19]$.

Sometimes measures of working time intervals, have been grouped with other measures of working time, such as non-professional activities [14], personal activities, or idle periods [18], they were even distinguished as physiological breaks [14]. It caused certain difficulties during a too shallow analysis, based only on numerical values portraying measures of working time intervals. Even close values, received by different authors, can be interpreted in completely different ways. It depends on organizational conditions' context, in which they are considered, most of all with inclusion of clinical specification of a given nursing workplace, they can point to tendencies close to results received by other authors $[14,17,18]$. Therefore, when they have been described in relation to, or in a context of operational mathematical values, significant deviations from recommended values, have been confirmed on nursing posts [7,11].

That is exemplified by the comparison of the author's and Cebulak and Ksykiewicz-Dorota research [14], which shows that physiological breaks in total working time stand at $12.28 \%$. Therefore, in accordance to the assumptions they represent a proper percentage rate of total working time, and as compared to values received by the author, they constitute a value that is almost 2 times lower. It should be assumed, that results are different, but it is not true because during the analysis of the author's results, taking into consideration only those that were connected with psychiatry wards, a similar result as to the time of intervals was received.

The results of Klukow and Ksykiewicz [18] can be analyzed in a similar manner. The intervals along with idle times and personal activities summed up to $3.76 \%$ for each nursing workplaces in the structure of hospital's rescue wards. 
Table 2. Statistical analysis with use of $\mathrm{Chi}^{2}$ test on chosen variables

Tabela 2. Analiza statystyczna z zastosowaniem testu $\mathrm{Chi}^{2}$ dla wybranych zmiennych

\begin{tabular}{|c|c|c|c|}
\hline $\begin{array}{l}\text { Correlated variable } \\
\text { Korelowana zmienna }\end{array}$ & $\mathrm{Chi}^{2}$ & Df & $\mathrm{p}$ \\
\hline \multicolumn{4}{|c|}{ Interval time vs. working place / Czas przerw vs miejsce pracy } \\
\hline total & 16.645 & 20 & 0.6759 \\
\hline group / grupa A & 19.715 & 20 & 0.4759 \\
\hline group / grupa B & 16.618 & 20 & 0.6776 \\
\hline \multicolumn{4}{|l|}{ Interval time vs. position / Czas przerw vs stanowisko } \\
\hline total & 17.109 & 20 & 0.6459 \\
\hline group / grupa A & 14.971 & 20 & 0.7781 \\
\hline group / grupa B & 25.258 & 20 & 0.1917 \\
\hline \multicolumn{4}{|l|}{ Interval time vs. seniority / Czas przerw vs staż pracy } \\
\hline total & 13.416 & 15 & 0.5702 \\
\hline group / grupa A & 8.765 & 10 & 0.5545 \\
\hline group / grupa B & 11.324 & 15 & 0.7293 \\
\hline \multicolumn{4}{|c|}{ Interval time vs. education level / Czas przerw vs wykształcenie } \\
\hline total & 17.364 & 15 & 0.2976 \\
\hline group / grupa A & 14.625 & 10 & 0.1463 \\
\hline group / grupa B & 17.432 & 15 & 0.2937 \\
\hline \multicolumn{4}{|c|}{ Interval time vs. time of direct care / Czas przerw vs czas opieki bezpośredniej } \\
\hline total & 14.474 & 10 & 0.1524 \\
\hline group / grupa A & 20.871 & 10 & $0.0220^{*}$ \\
\hline group / grupa B & 11.927 & 10 & 0.2899 \\
\hline \multicolumn{4}{|c|}{ Interval time vs. time of indirect care / Czas przerw vs czas opieki pośredniej } \\
\hline total & 25.910 & 10 & $0.0039^{* *}$ \\
\hline group / grupa A & 10.870 & 10 & 0.3677 \\
\hline group / grupa B & 15.114 & 10 & 0.1279 \\
\hline
\end{tabular}

Groups as in Table 1.

$\mathrm{Chi}^{2}$ - Chi-square test for independence / test zgodności Chi kwadrat, Df - degree of freedom / stopień swobody.

Yates p-value / Wartość p z poprawką Yatesa: ${ }^{\star} 0.12813816,{ }^{* *} 0.02391266$.

Table 3. Statistical analysis with the use of Fisher's exact test of chosen variables

Tabela 3. Analiza statystyczna z zastosowaniem dokładnego testu Fishera wybranych zmiennych

\begin{tabular}{|c|c|c|c|}
\hline \multirow{2}{*}{$\begin{array}{l}\text { Correlated variable } \\
\text { Korelowana zmienna }\end{array}$} & \multirow{2}{*}{ Phi } & \multicolumn{2}{|c|}{$\mathrm{p}$} \\
\hline & & $\begin{array}{c}\text { 1-tailed } \\
\text { jednostronne }\end{array}$ & $\begin{array}{l}\text { 2-tailed } \\
\text { dwustronne }\end{array}$ \\
\hline $\begin{array}{l}\text { Time of intervals vs. time of direct care (both groups - total) / Czas przerw vs czas } \\
\text { opieki pośredniej (obie grupy ogółem) }\end{array}$ & -0.09 & 0.0410 & 0.0709 \\
\hline
\end{tabular}

Phi - Fisher test / test Fishera.

Their interpretation is obvious and shows that it is just like in the author's survey that points out to huge deviations from the set standards. In this research connected with observation of working time on nursing workplaces, authors put special emphasis on improper use of time in matters of respective groups, essentially underlining the fact that working time structure is improper as well. Most of the time is spent on indirect care, including administration activities [13-19]. It often happens at a cost of working time intervals, which is also confirmed by the author's survey. In workplaces requiring intensive medical care or nursing care, dependent on the degree of a patient's state, it sometimes imposes a cost on direct care [13-19]. Actions oriented on counteracting this state of things, that are pointed out most commonly, include those that would allow to shorten the time of indirect 
Table 4. Characteristics of the group in which a proper structure of working time has been received Tabela 4. Charakterystyka grupy, w której uzyskano prawidłową strukturę czasu pracy

\begin{tabular}{|c|c|c|}
\hline \multirow[t]{2}{*}{$\begin{array}{l}\text { Variable } \\
\text { Zmienna }\end{array}$} & \multicolumn{2}{|c|}{$\begin{array}{l}\text { Respondents } \\
\text { Respondenci } \\
\quad(\mathrm{N}=177)\end{array}$} \\
\hline & $\mathrm{n}$ & $\%^{*}$ \\
\hline \multicolumn{3}{|l|}{ Workplace / Miejsce pracy } \\
\hline non-treatment specifity / specyfika niezabiegowa & $26(149)$ & 17.4 \\
\hline treatment specifity / specyfika zabiegowa & $16(73)$ & 21.9 \\
\hline intensive care unit / intensywny nadzór medyczny & $11(58)$ & 18.0 \\
\hline non-specific nursing workplaces / niespecyficzne miejsca pracy pielęgniarskiej & $13(102)$ & 12.7 \\
\hline \multicolumn{3}{|l|}{ Position / Stanowisko } \\
\hline general nurse / pielęgniarki odcinkowe & $37(228)$ & 16.2 \\
\hline $\begin{array}{l}\text { nurse managers and other independent positions / pielęgniarska kadra zarządzająca i inne } \\
\text { samodzielne pielęgniarki }\end{array}$ & $17(78)$ & 21.8 \\
\hline $\begin{array}{l}\text { functional nurses (working system } 1 \text { shift) / pielęgniarki funkcyjne (system } \\
\text { pracy 1-zmianowy) }\end{array}$ & $9(42)$ & 21.4 \\
\hline $\begin{array}{l}\text { non-specific working positions (12-h system) / niespecyficzne stanowiska pracy } \\
\text { (system 12-godzinny) }\end{array}$ & $4(26)$ & 15.4 \\
\hline \multicolumn{3}{|l|}{ Seniority [years] / Staż pracy [w latach] } \\
\hline$\leq 5$ & $11(101)$ & 10.9 \\
\hline $6-15$ & $13(87)$ & 14.9 \\
\hline$\geq 16$ & $39(185)$ & 21.1 \\
\hline lack of answer / brak odpowiedzi & $4(11)$ & 36.4 \\
\hline \multicolumn{3}{|l|}{ Education level / Wykształcenie } \\
\hline secondary education (vocational) / średnie (liceum, studium medyczne) & $13(65)$ & 20.0 \\
\hline bachelor of nursing / licencjat pielęgniarstwa & $47(282)$ & 16.7 \\
\hline $\begin{array}{l}\text { master degree in nursing or other university degree / magister pielęgniarstwa lub inne wyższe } \\
\text { studia magisterskie }\end{array}$ & $3(10)$ & 30.0 \\
\hline lack of answer / brak odpowiedzi & $4(27)$ & 14.8 \\
\hline
\end{tabular}

* Results does not sum up to $100 \%$ / Wyniki nie sumują się do $100 \%$.

care $[14,17-19]$. This gains special importance in relation to the author's survey results, based on statistical data, confirming correlation between time of intervals and measure of indirect care.

Solutions proposing creation of help-oriented workplaces for a strictly medical profession would be most helpful: a nursing assistant, nursing secretary or cleaning staff, etc. In relation to own survey results, it appears that most essential would be the solutions connected with optimization of administrative work at nursing workplaces, that is, removal of the duty to keep double patient records or to rule out what truly does not bring anything to effectiveness of a patient's health care process.

Moreover at such specific workplaces, the main purpose of which is to take care of other human beings, it should not be forgotten that, "Time of work is the time, during which, an employee is at employer's disposal at workplace or another place set for conducting work" [20], therefore also during the preparedness to conduct immediate actions, such as reanimation process. That is why in the case of nursing workplaces, the system is expected to organize working time, allowing for proper time management [21], determining an employee's and a patient's comfort of work/care, resulting from safe working time frames, set for given actions. It should be underlined that the most essential role in this process is held by management [7].

\section{CONCLUSIONS}

Based on the gathered survey material, final conclusions have been formulated:

1. Received values in matters of measures of work intervals on nursing positions are a sign of significant deviations (at the level of 50\%) from assumed standards, which along with maintained for a longer period of time longer working hours, may cause decrease in efficiency of work and cause a drop in quality of provided services.

2. Due to the importance of problems of working time measures, including proper measure of working time 
intervals on nursing positions, training process of nursing care should be brought to special attention. In practice this would allow to systematically analyze it, giving a base for the right staff oriented decisions.

\section{REFERENCES}

1. Kwiecień K, Wujtewicz M, Mądrzycka-Dąbrowska W. Selected methods of measuring workload among intensive care nursing staff. Int J Occup Med Environ Health. 2012;25(3):209-17, http://dx.doi.org/10.2478/S13382012-0035-5.

2. Wiskow C. [Workload measurement determining staffing levels: A literature review]. Geneva: International Council of Nurses; 2006 [cited 2014 Jul 1]. Available from: http:// www.ptp.na1.pl/pliki/ICN/ICN_pomiar_obciazenia_ praca_03_11_2009.pdf. Polish.

3. Kuriata E, Felińczak A, Grzebieluch J, Szachniewicz M. [Occupational hazards and the workload of nurses employed at the hospital. Part II]. Pielęg Zdrow Publiczne. 2011;1(3):269-73. Polish.

4. Karczewski JK. [Types of workload detrimental factors]. In: Karczewski JK. [Hygiene]. Lublin: Wydawnictwo Czelej; 2002. p. 233-60. Polish.

5. Gaweł G. [Working time. Shift work]. In: Ksykiewicz-Dorota A, editor. [Fundamentals of nursing. Job organizations]. Lublin: Wydawnictwo Czelej; 2004. p. 118-21. Polish.

6. Antoszkiewicz JD, Piech K. [Diagnosing of execution Team work testing methods]. In: Antoszkiewicz JD, editor. [Methods for solving problems in a small business. Monographs and Studies No. 467]. Warszawa: Oficyna Wydawnicza SGH; 1999. p. 80-1. Polish.

7. Wojtowicz A, Pyrek R. [Essence and working time models]. Malopolska Sch Econ Tarnów Res Pap Collect. 2008;1(1):139-54. Polish.

8. Wróblewska M. [Ergonomy. The script for the students. Script No. 265]. Opole: Oficyna Wydawnicza Politechniki Opolskiej; 2004. p. 99-101, 104-6. Polish.

9. Czarnecka-Wójcik E, Wójcik M. [Photography of the Working day]. In: Bieniok H. [Methods for efficient management. Planning, organizing, motivating, control]. Warszawa:
Agencja Wydawniczo-Poligraficzna PLACET; 1997. p. 114-35. Polish.

10. Ksykiewicz-Dorota A. [Measurement and standardization work].In:Ksykiewicz-Dorota A, editor. [Management in nursing]. Lublin: Wydawnictwo Czelej; 2005. p. 401-6. Polish.

11. Gaweł G. [Fatigue breaks at different positions in the nursing subsystem]. In: Ksykiewicz-Dorota A, editor. [Management in nursing]. Lublin: Wydawnictwo Czelej; 2005. p. 458-62. Polish.

12. Gaweł G. [Burden on nursing positions]. In: KsykiewiczDorota A, editor. [Fundamentals of nursing. Job organizations]. Lublin: Wydawnictwo Czelej; 2004, p. 110-17. Polish.

13. Ksykiewicz-Dorota A. [Planning for nursing stocking densities in therapeutics stationary]. Lublin: Wydawnictwo Czelej; 2001. Polish.

14. Cebulak M, Ksykiewicz-Dorota A. [The characteristics of the work of the nurses in a psychiatric ward versus the utilization of working time]. Probl Pielęg. 2011;19(4):424-30. Polish.

15. Whittington D, McLaughlin C. Finding time for patients: An exploration of nurses' time allocation in an acute psychiatric setting. J Psychiatr Ment Health Nurs. 2000;7(3): 259-68, http://dx.doi.org/10.1046/j.1365-2850.2000.00291.x.

16. Furåker C. Nurses' everyday activities in hospital care. J Nurs Manag. 2009;17(3):269-77, http://dx.doi.org/10. 1111/j.1365-2934.2007.00832.x.

17. Ksykiewicz-Dorota A, Wysokiński M, Kurek M. [Norms staffs nurses in intensive care units and centers of artificial kidney]. Zdrow Publiczne. 2002;112(1):55-9. Polish.

18. Klukow J, Ksykiewicz-Dorota A. [Structure of nurses' work in hospital casualty and emergency wards - Preliminary study]. Pielegniarstwo XXI. 2010;3-4(32-33):55-9. Polish.

19. Markiewicz I, Ksykiewicz-Dorota A. [Working time at nursing workplaces in long - Term care facilities]. Zdrow Publiczne. 2009;119(3):288-92. Polish.

20. [Labour Code Act as amended of 1974 June 25. J Laws 1974, No. 24, item 141] [cited 2015 Mar 24]. Available from: http://isap.sejm.gov.pl/DetailsServlet?id=WDU197402 40141. Polish.

21. Kozioł L, Pyrek R. [Working time management model in an enterprise]. Małopolska Sch Econ Tarnów Res Pap Collect. 2009;2(13):339-50. Polish.

\footnotetext{
The use of the article "Working time intervals and total work time on nursing positions in Poland" is available in Open Access model permitted under license conditions of Creative Commons Attribution-NonCommercial 3.0 (also known as CC-BY-NC), available at http://creativecommons.org/licenses/by-nc/3.0/pl/ or another language version of this license or any later version of this license published by Creative Commons / Zezwala się na korzystanie z artykułu „Wymiar czasu przerw w pracy a całkowity czas pracy na stanowiskach pielęgniarskich w Polsce" w modelu open access na warunkach licencji Creative Commons Uznanie autorstwa - Użycie niekomercyjne 3.0 (znanej również jako CC-BY-NC), dostępnej pod adresem http://creativecommons.org/licenses/by-nc/3.0/pl/ lub innej wersji językowej tej licencji lub którejkolwiek późniejszej wersji tej licencji, opublikowanej przez organizację Creative Commons.
} 